\title{
LEVEL OF 25-HYDROXYVITAMIN D IN PEDIATRIC ARTHRITIS PATIENTS
}

\author{
Marta Laizāne ${ }^{1,3,}$ \# leva Saulīte ${ }^{1,2}$, Sandra Feierābende ${ }^{1}$, \\ and Ingrīda Rumba-Rozenfelde ${ }^{1,2}$

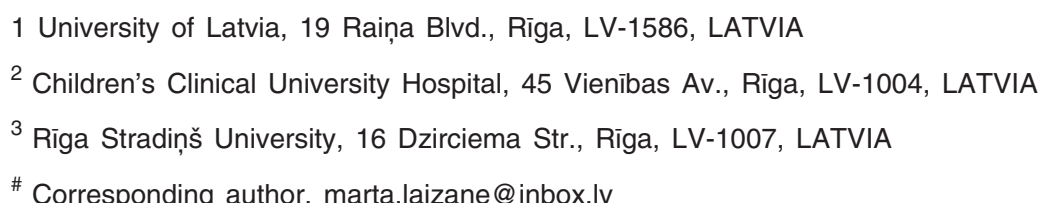

Contributed by Ingrĩda Rumba-Rozenfelde

\begin{abstract}
Vitamin $D$ deficiency is common and widespread globally. Vitamin $D$ has an immunomodulatory effect, but it is still unclear whether its deficiency is associated with higher disease activity. The aim of this retrospective study was to determine the serum concentration of vitamin $D$ in children with paediatric arthritis (juvenile idiopathic arthritis and reactive arthritis). Prevalence of hypovitaminosis $D$ among 98 children with juvenile idiopathic arthritis and reactive arthritis was determined and association between serum concentration of vitamin $D$ and disease activity markers was found. Prevalence of vitamin D deficiency among children included in this study was $69.07 \%$. Children with juvenile idiopathic arthritis had a significantly lower vitamin D level than children with reactive arthritis. There was a statistically significant moderate negative correlation between serum concentration of vitamin $D$ and patient age, as well as a weak negative correlation between vitamin $D$ level and patient body mass index. The significant correlations found between vitamin $D$ level and inflammatory markers indicate that further research on the role of vitamin $D$ in disease activity is needed.
\end{abstract}

Key words: vitamin $D$, juvenile idiopathic arthritis, reactive arthritis.

\section{INTRODUCTION}

Vitamin D deficiency is common and widespread globally. On average, $13 \%$ of Europeans have a vitamin D level below $30 \mathrm{ng} / \mathrm{ml}$, which is considered as a deficit (Cashman et al., 2016). Vitamin D has traditionally been important in the metabolism of calcium and phosphorus, but in recent years new evidence has shown that vitamin D plays a major role in the regulation of immunity and that its deficiency is associated with a more severe course of rheumatic diseases. For several years, vitamin $\mathrm{D}$ has been known to have an immunomodulatory effect (Myszka et al., 2014), but it is still unclear whether its deficiency is associated with higher disease activity in rheumatologic patients.

Vitamin D is capable of binding to the vitamin D receptor (VDR), which is found in many target tissues such as bones, intestines, kidneys and brain (Christakos et al., 2003; Pike and Meyer, 2012). Vitamin D receptor (VDR) plays an im- portant role in achieving the biological effects of vitamin D. It is a hormonal receptor found in the cell nucleus and is specifically activated by $1,25(\mathrm{OH})_{2} \mathrm{D}_{3}$ (Yasmin et al., 2005; Pike et al., 2012). VDR binds to $1,25(\mathrm{OH})_{2} \mathrm{D}_{3}$, and regulation of gene transcription is carried out, which results in production of specific proteins that implement vitamin $\mathrm{D}_{3}$ functions.

Many tissues and immune cells express VDR and enzymes required for local $1,25(\mathrm{OH})_{2} \mathrm{D}_{3}$ production. The activity of these enzymes is induced by other unknown factors. By discovering these factors, it could be easier to understand the role of vitamin $\mathrm{D}$ in pathogenesis of autoimmune diseases (Raman et al., 2011).

More than 200 single nucleotide polymorphisms (SNPs) that determine the activity of this receptor have been detected in the VDR gene. VDR polymorphic alleles are risk factors for diseases such as celiac disease, SLE, autism 
spectrum disorders and many others (Booth et al., 2016; Cieślińska et al., 2017). Studies are ongoing to investigate the effects of VDR polymorphisms on the risk of developing rheumatoid arthritis (RA). Kalthoum and Kamel (2015), in a meta-analysis of 12 studies, concluded that the VDR gene TaqI and FokI polymorphisms have an impact on the risk of RA development.

$1,25(\mathrm{OH})_{2} \mathrm{D}$ acts on the immunity through VDR located in most of the cells in immune system, especially antigen presenting cells - monocytes, macrophages and dendritic cells. Further, $1,25(\mathrm{OH})_{2} \mathrm{D}$ induces hereditary immunity and inhibits the acquired immunity. Thus, vitamin D plays a role in both infections and autoimmune diseases (Mangin et al., 2014).

Vitamin D can modulate cytokine response and reduce Toll-like receptor (TLR) activation, thereby reducing both local and systemic inflammation (Jeng et al., 2009). $1,25(\mathrm{OH})_{2} \mathrm{D}_{3}$ acting on monocyte VDR induces the expression of antimicrobial peptide (antimicrobial peptide (AMPs), such as cathelicidin and beta defensin (Mangin et al., 2014). As VDR are found in many different cells of the immune system, including dendritic cells and activated T-lymphocytes, the effect of vitamin D on acquired immunity can be realised directly by action on T-lymphocytes and indirectly by modulating the response of dendritic cells. In vitro vitamin $\mathrm{D}$ can inhibit monocyte differentiation into dendritic cells and stimulate the development of dendritic cells with tolerogenic properties, i.e. the ability to be immunolabeled (Penna and Adorini, 2000). Vitamin D has also been reported to inhibit the production of CD4 + T-lymphocyte interferon $\gamma$ (Staeva-Vieira and Freedman, 2002) and interleukin 17 (IL-17) (Ikeda et al., 2010).

Tumour necrosis factor-alpha (TNF- $\alpha$ ) is a cell signalling protein. It is one of the cytokines that creates the acute phase reaction. TNF- $\alpha$ is mainly produced by activated macrophages, although it can also be secreted by many other cell types, such as CD4 + lymphocytes, NK cells, neutrophils, white cells, eosinophilic leukocytes, adipocytes, fibroblasts, and neurons (Popa et al., 2007). Many TNF- $\alpha$-producing cell nuclei contain VDR (Cantoma, 2000; Cantorna et al., 2004), making it difficult to distinguish specific mechanisms by which $25(\mathrm{OH})$ vitamin $\mathrm{D}$ can affect circulating TNF- $\alpha$ concentrations. Experimental results show that vitamin D can suppress TNF- $\alpha$ production. Studies with humans show a positive effect of vitamin D on TNF- $\alpha$ concentration. For example, in patients with chronic heart failure serum TNF- $\alpha$ levels gradually increased during a period of nine months, whereas in patients with the same diagnosis, supplemented with vitamin D therapy (2000 IU/day), serum TNF- $\alpha$ remained constant (Schleithoff et al., 2006). Similarly, treatment with calcitriol $\left(1,25(\mathrm{OH})_{2} \mathrm{D}_{3}\right)$ for six months in postmenopausal women with osteoporosis resulted in a significant decrease in serum TNF- $\alpha$ concentration (Inanir et al., 2004).

Recently, evidence has come to light that the risk of developing various diseases depends on the birth season. A retro- spective study conducted in 2015 analysed the levels of serum 25-hydroxyvitamin $\mathrm{D}$ in 1,145 adult patients who were stratified according to year of birth. Serum vitamin D levels were significantly lower in patients born in winter than those born in spring and summer. Specifically, the winter season was associated with an $11 \%$ higher risk of developing vitamin $\mathrm{D}$ deficiency later in life compared to springtime when there is a longer period of daylight (Lippi et al., 2015). However, in a similar study conducted in Norway in 2016, in which 10203 patients were studied, no relationship was found between the month of birth and the level of vitamin D in later life (Zostautiene et al., 2016).

The aim of our study was to determine the level of vitamin $\mathrm{D}$ in patients with juvenile idiopathic arthritis and reactive arthritis. In Latvia, vitamin D levels in children with arthritis have not been analysed.

\section{MATERIALS AND METHODS}

In a retrospective study conducted from 2016 to 2017, 98 patients at the Children's Clinical University Hospital "Gail,ezers" were analysed. Patient age was from 1 to 18 years (average $12.28+/-4.26$ years). The group consisted of 59 girls and 35 boys diagnosed with juvenile idiopathic arthritis (JIA) and reactive arthritis $(\operatorname{ReA})$.

The patients were divided into two groups according to diagnosis - patients with JIA $(\mathrm{n}=55)$ and patients with postviral $\operatorname{ReA}(n=40)$. We analysed separately the JIA patient group with severe disease - high disease activity, persistent high disease activity, polyarthritis and frequent flares $(n=22)$.

The following parameters were collected from patient medical records - date of birth, age, sex, height, weight, calculated body mass index (BMI), total $25(\mathrm{OH})$ vitamin $\mathrm{D}$ in serum, rheumatoid factor (RF), antinuclear antibodies (ANA), anti-DNA antibodies (anti-dsDNA), TNF-alpha (TNF $\alpha$ ), leukocytes count (WBC), erythrocyte sedimentation rate (ESR), C-reactive protein (CRP), haemoglobin level (Hb), and HLA-B27. The serum concentration of $25(\mathrm{OH}) \mathrm{D}$ was determined by immune chemiluminescence (Roche).

The average vitamin D levels were determined for children born each month. We also calculated the average UV index of each month in 2017, based on data of the Latvian Environment, Geology and Meteorology Agency (www.meteo.lv).

Statistical analysis was performed using IBM SPSS 22.0.

\section{RESULTS}

The determined values of vitamin $\mathrm{D}$, body mass index (BMI) and laboratory markers of autoimmunity are shown in Table 1. The average level of vitamin D among patients was low: $25.26 \pm 9.02 \mathrm{ng} / \mathrm{ml}$ with range from 8.17 to 52.71 $\mathrm{ng} / \mathrm{ml}$ (Fig. 1). Vitamin D levels in girls were significantly 
MINIMUM, MAXIMUM, AND MEAN VALUES FOR VITAMIN D, INFLAMMATORY MARKERS AND BMI IN THE JIA AND REA PATIENT GROUPS

\begin{tabular}{|c|c|c|c|c|c|}
\hline \multicolumn{2}{|c|}{ Patient groups } & $\begin{array}{c}25(\mathrm{OH}) \mathrm{D}, \\
\mathrm{ng} / \mathrm{ml}\end{array}$ & $\mathrm{RF}, \mathrm{IU} / \mathrm{ml}$ & ANA, IU/ml & BMI, $\mathrm{kg} / \mathrm{m}^{2}$ \\
\hline \multirow[t]{4}{*}{$\operatorname{ReA}$} & $\mathrm{n}$ & 39 & 34 & 28 & 31 \\
\hline & Min & 11.84 & 3.1 & $\mathrm{Neg}$ & 14.05 \\
\hline & $\operatorname{Max}$ & 45.81 & 8.6 & Neg & 24.69 \\
\hline & Mean & 27.44 & 6.93 & $\begin{array}{c}\mathrm{Neg}: \mathrm{pos}= \\
23: 5\end{array}$ & 17.85 \\
\hline \multicolumn{2}{|c|}{$p^{*}$} & 0.036 & 0.028 & 0.029 & \\
\hline \multirow[t]{4}{*}{ JIA } & $\mathrm{n}$ & 59 & 52 & 43 & 40 \\
\hline & Min & 8.17 & 4.8 & $\mathrm{Neg}$ & 14.95 \\
\hline & Max & 52.71 & 121.4 & Pos & 29.38 \\
\hline & Mean & 24.12 & 10.21 & $\begin{array}{c}\text { Neg: }: \text { pos }= \\
27: 16\end{array}$ & 19.83 \\
\hline
\end{tabular}

$p^{*}$ - comparing JIA and ReA patient groups; data are statistically significant if $p<0.05$.

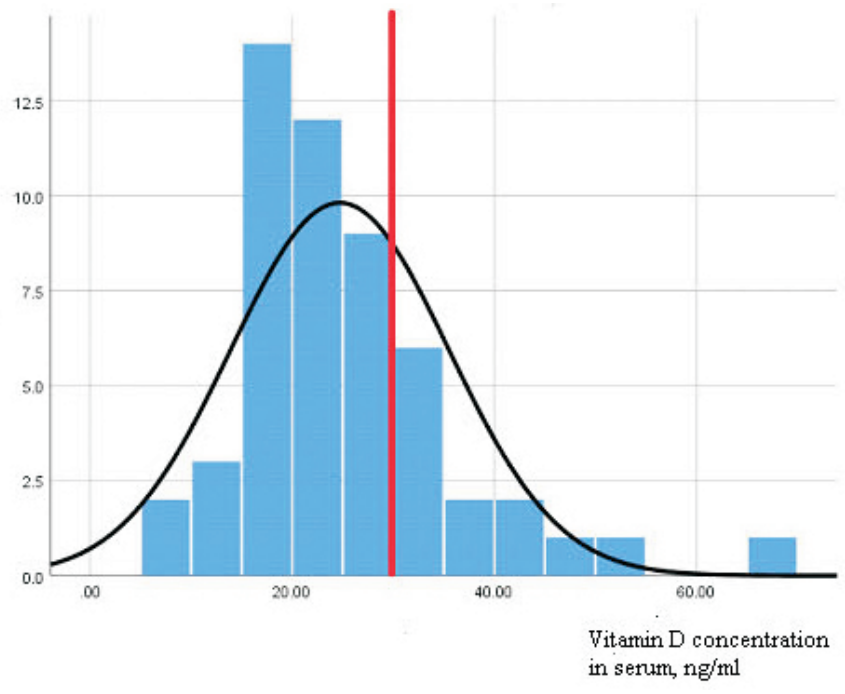

Fig. 1. Normal distribution of serum vitamin D levels among all patients included in the study (red marked $30 \mathrm{ng} / \mathrm{ml}$; the lower level being considered as vitamin D deficiency).

lower than in boys $(24.05 \mathrm{ng} / \mathrm{ml}$ and $28.09 \mathrm{ng} / \mathrm{ml}$, respectively; $p=0.022$ ). In children with juvenile idiopathic arthritis, the average vitamin $\mathrm{D}$ level $(24.12 \mathrm{ng} / \mathrm{ml}$, range $8.17-52.71 \mathrm{ng} / \mathrm{ml})$ was significantly lower $(p=0.036)$ than in children with reactive arthropathy $(27.44 \mathrm{ng} / \mathrm{ml}$; range $11.84-45.81 \mathrm{ng} / \mathrm{ml})$.

We tested for differences in laboratory data for patient groups depending on vitamin D levels (Table 2). Vitamin D deficiency $(25(\mathrm{OH})$ D below $30 \mathrm{ng} / \mathrm{ml})$ was found in a total of $69.07 \%$ of children $(n=67)$. A statistically significant difference $(p=0.008)$ was observed between RF levels in patients with vitamin $\mathrm{D}$ deficiency $(25(\mathrm{OH})$ D below 30 $\mathrm{ng} / \mathrm{ml}$ ) and normal vitamin D levels $(25(\mathrm{OH}) \mathrm{D}$ below 30 $\mathrm{ng} / \mathrm{ml}$ ) (see Table 2). A statistically significant difference between these groups was also observed for the level of
MEAN VALUES OF AGE, BMI AND INFLAMMATORY MARKERS IN PATIENTS WITH AND WITHOUT VITAMIN D DEFICIENCY

\begin{tabular}{lcccc}
\hline \multicolumn{1}{c|}{ Parameters } & $\begin{array}{c}25(\mathrm{OH}) \mathrm{D} \text { below } \\
30 \mathrm{ng} / \mathrm{ml}(\mathrm{n}=67)\end{array}$ & $\begin{array}{c}25(\mathrm{OH}) \mathrm{D} \text { higher than } \\
\text { 30ng/ml }(\mathrm{n}=32)\end{array}$ & $p^{*}$ \\
\hline 25(OH)D, ng/ml & $20.58 \pm 5.29$ & $36.97 \pm 5.69$ & $0.000^{*}$ \\
Age, years & $13.32 \pm 3.66$ & $9.9 \pm 4.79$ & 0.491 \\
$\mathrm{RF}, \mathrm{IU} / \mathrm{ml}$ & $7.47 \pm 3.50$ & $11.48 \pm 21.59$ & $0.008^{*}$ \\
anti-DNA, IU/ml & $8.15 \pm 5.87$ & $8.61 \pm 6.61$ & $0.033^{*}$ \\
TNF- $\alpha, \mathrm{pg} / \mathrm{ml}$ & $6.82 \pm 2.68$ & $8.11 \pm 3.70$ & 0.688 \\
$\mathrm{CRP}, \mathrm{mg} / \mathrm{l}$ & $1.86 \pm 7.55$ & $2.74 \pm 7.04$ & $0.013^{*}$ \\
$\mathrm{ESR}, \mathrm{mm} / \mathrm{h}$ & $6.81 \pm 7.03$ & $13.29 \pm 17.43$ & 0.620 \\
$\mathrm{WBC}, \mathrm{x} 10^{\wedge} 3 / \mathrm{ul}$ & $7.67 \pm 2.48$ & $8.84 \pm 3.37$ & 0.997 \\
$\mathrm{Hb}, \mathrm{g} / \mathrm{dl}$ & $13.56 \pm 1.27$ & $13.02 \pm 0.93$ & 0.130 \\
$\mathrm{BMI}, \mathrm{kg} / \mathrm{m}^{2}$ & $19.71 \pm 3.43$ & $17.01 \pm 2.30$ & $0.001^{*}$ \\
\end{tabular}

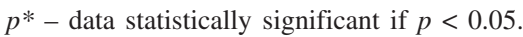

anti-DNA antibodies $(p=0.033), \mathrm{CRP}(p=0.013)$ and BMI $(p=0.001)$.

The $25(\mathrm{OH})$ D level was significantly correlated with TNF-alpha and ESR both in the JIA group and in the overall patient population (Table 3 ). There is a statistically significant moderate negative correlation between vitamin $\mathrm{D}$ level and patient age $(\mathrm{r}=0.443 ; p=0)$. This correlation is also seen in JIA patients $(\mathrm{r}=0.481 ; p=0)$. There is a weak negative correlation between vitamin $\mathrm{D}$ level and BMI, which was statistically significant $(r=0.372, p=0.002)$. There was also a moderate correlation between anti-DNA antibody and vitamin D level $(\mathrm{r}=-0.401, p=0.017, \mathrm{n}=36)$ in the arthropathy group.

There was a weak negative correlation between the mean monthly value of vitamin $\mathrm{D}$ for children and the average monthly UV index, which was not statistically significant ( $\mathrm{r}=0.395, p=0.204)$ (Fig. 2).

The average total leukocyte count (WBC) in both JIA and ReA patients was $8.08 \pm 2.89(4-20.2)$ thousands per $1 \mathrm{~mm}^{3}$ of peripheral blood. There was no statistically significant difference in leukocyte count between JIA and ReA patients $(p=0.153)$. There was also no statistically significant correlation between vitamin $\mathrm{D}$ level and leukocyte count.

\section{DISCUSSION}

The results of literature on the level of vitamin D in children with arthritis are contradictory. The average vitamin $\mathrm{D}$ level among patients included in our study was $25.26 \pm 9.02$ (8.17-52.71) $\mathrm{ng} / \mathrm{ml}$. In a comparative study of 50 JIA patients living in Brazil, the average vitamin D level was 31.6 $\pm 10.0 \mathrm{ng} / \mathrm{ml}$, which was higher than in the control group of $30.4 \pm 5.7 \mathrm{ng} / \mathrm{ml}(p>0.05)$ (De Sousa Studart et al., 2015). However, Stagi et al. (2014) reported a significantly lower 
CORRELATIONS BETWEEN SERUM 25 (OH) D LEVELS AND INFLAMMATORY MARKERS, AGE AND BMI

\begin{tabular}{|c|c|c|c|c|c|c|c|c|c|c|}
\hline Patient groups & & $\mathrm{RF}, \mathrm{IU} / \mathrm{ml}$ & $\begin{array}{c}\text { anti-DNA, } \\
\mathrm{IU} / \mathrm{ml}\end{array}$ & $\begin{array}{l}\text { TNF- } \alpha, \\
\mathrm{pg} / \mathrm{ml}\end{array}$ & $\mathrm{CRP}, \mathrm{mg} / \mathrm{l}$ & $\mathrm{ESR}, \mathrm{mm} / \mathrm{h}$ & $\begin{array}{c}\text { WBC, } \\
\times 10^{\wedge} 3 / \mathrm{ul}\end{array}$ & $\mathrm{Hb}, \mathrm{g} / \mathrm{dl}$ & Age, years & $\begin{array}{c}\mathrm{BMI}, \\
\mathrm{kg} / \mathrm{cm}^{2}\end{array}$ \\
\hline \multirow[t]{2}{*}{ Reactive arthritis } & $R$ & 0.18 & -0.401 & 0.39 & -0.01 & -0.036 & 0.164 & -0.247 & -0.31 & $-0.39 *$ \\
\hline & $p^{*}$ & 0.919 & $0.017^{*}$ & 0.081 & 0.941 & 0.852 & 0.338 & 0.153 & 0.055 & 0.031 \\
\hline \multirow[t]{2}{*}{ JIA (with severe JIA) } & $R$ & -0.042 & 0.03 & 0.698 & 0.2 & 0.769 & 0.499 & -0.107 & -0.69 & -0.434 \\
\hline & $p^{*}$ & 0.869 & 0.898 & $0.008^{*}$ & 0.425 & $0.001 *$ & $0.042 *$ & 0.672 & $0.001 *$ & 0.121 \\
\hline \multirow{2}{*}{$\begin{array}{l}\text { JIA (patients with moderate } \\
\text { and self- limiting course) }\end{array}$} & $R$ & 0.154 & 0.142 & 0.381 & 0.092 & 0.446 & 0.19 & 0.032 & -0.481 & -0.305 \\
\hline & $p^{*}$ & 0.284 & 0.306 & $0.024 *$ & 0.521 & $0.002 *$ & 0.165 & 0.803 & $0.000^{*}$ & 0.059 \\
\hline \multirow[t]{2}{*}{ All patients } & $R$ & 0.107 & -0.029 & 0.347 & 0.024 & 0.303 & 0.145 & -0.041 & -0.443 & -0.372 \\
\hline & $p^{*}$ & 0.331 & 0.79 & $0.009 *$ & 0.874 & $0.007^{*}$ & 0.17 & 0.701 & $0.000 *$ & $0.002 *$ \\
\hline
\end{tabular}

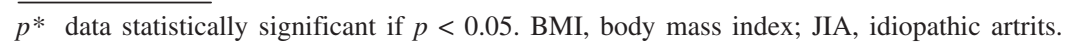

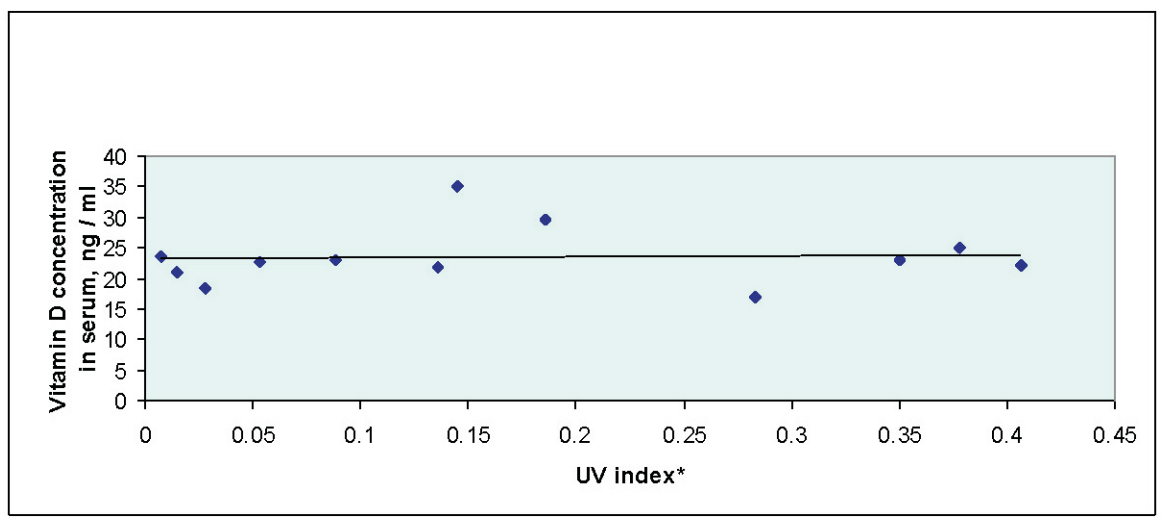

Fig. 2. Average vitamin D concentration in patients depending on their birth month average UV Index.

Data of Latvian Environment, Geology and Meteorology Centre, 2017 level of $25(\mathrm{OH}) \mathrm{D}$ in patients with JIA than in the control group $(p<0.001)$. In JIA patients in Turkey, an average vitamin D level of $17.7 \pm 11.6 \mathrm{ng} / \mathrm{ml}$ was observed (Çomak et al., 2014). In Latvia, the vitamin D level has also been studied in the adult population. Semjonova and Rasa (2012) analysed data of 3868 people and determined that the average vitamin D level was $21.1 \mathrm{ng} / \mathrm{ml}$, which was lower than in our study $-25.26 \pm 9.02(8.17-52.71) \mathrm{ng} / \mathrm{ml}$. In a similar study using 4809 patient data from the Latvian Central Laboratory database, the average level of $25(\mathrm{OH})$ vitamin D was $20.1 \mathrm{ng} / \mathrm{ml}$ (Mukane et al., 2015).

In JIA patients in Turkey, an average vitamin D level of $17.7 \pm 11.6 \mathrm{ng} / \mathrm{ml}$ was observed, of whom in $53.2 \%$ of patients the serum $25(\mathrm{OH})$ vitamin $\mathrm{D}$ was below $15 \mathrm{ng} / \mathrm{ml}$ (Çomak et al., 2014). Similar data were obtained in our study - a 25(OH) vitamin D level below $30 \mathrm{ng} / \mathrm{ml}$ was found in $72.41 \%$ JIA patients, and a level below $15 \mathrm{ng} / \mathrm{ml}$ only in $12.07 \%$.

In literature, female gender is often referred to as a risk factor for hypovitaminosis D (Mithal et al., 2009; Verdoia et al., 2015). For example, Verdoia et al. (2015) reported that women had not only lower vitamin D levels than men (14.5 \pm 10.9 vs. $15.9 \pm 9.5 \mathrm{ng} / \mathrm{ml} ; p=0.007)$, but also more frequent severe vitamin $\mathrm{D}$ deficiency $(41.9 \%$ vs. $30.4 \%, p<$ $0.001)$. Also, in our study $25(\mathrm{OH})$ vitamin $\mathrm{D}$ serum levels in girls were on average lower than in boys, $24.05 \mathrm{ng} / \mathrm{ml}$ and $28.09 \mathrm{ng} / \mathrm{ml}$, respectively $(p=0.022)$. The low level of vitamin $\mathrm{D}$ in women compared to men is explained by the fact that vitamin $\mathrm{D}$ is deposited in adipose tissue and women have a higher percentage of body fat (Gharaibeh et al., 2009).

Many literature sources have reported a negative association between vitamin D level and age (Mithal et al., 2009; Anonymous, 2014; Hajjaj-Hassouni et al., 2017). This trend might be explained by vitamin $\mathrm{D}$ replacement therapy given often to infants and toddlers, which is discontinued as the child grows. Also, older children and adolescents tend to spend more time indoors.

A negative correlation between vitamin $\mathrm{D}$ level and body mass index (BMI) has been described in literature (O'Dell et al., 2002; Rovner et O'Brien, 2008; Anonymous, 2014; Bani-issa et al., 2017; Elizondo-Montemayor et al., 2017; Hajjaj-Hassoun et al., 2017; Kumaratne et al., 2017). For example, Bani-issa et al. (2017) found that in patients with BMI of $30 \mathrm{~kg} / \mathrm{m}^{2}$ or more, there was a risk of more than five times for vitamin $\mathrm{D}$ deficiency than for patients with BMI below $25 \mathrm{~kg} / \mathrm{m}^{2}$. A negative association between the patient's BMI and serum vitamin D levels was also observed in our study $(\mathrm{r}=-0.372 ; p=0.002)$, which is similar to the results of Sadiya et al. (2014) ( $\mathrm{r}=0.15 ; p=0.01)$. Wortsman et al. (2010) reported a correlation $\mathrm{r}=-0.55$ ( $p=$ 0.003 ) in study groups with adipose and normal body mass, and suggested that adipose persons have reduced bioavailability of vitamin D from skin and dietary sources, because vitamin D tends to deposit in adipose tissue. Other authors consider that vitamin D hypovitaminosis in adipose 
patients is explained by the synthesised and absorbed volumetric dilution of vitamin $\mathrm{D}$, rather than sequestration in increased fat tissue (Drincic et al., 2012). It is also possible that adipose patients have less exposure to direct sunlight due to reduced physical activity (Cheng et al., 2010; Ahmadieh et al., 2013). In some studies, no correlation was found between vitamin D levels and BMI (De Sousa Studart et al., 2015).

In children with juvenile idiopathic arthritis, vitamin D levels were significantly $(p=0.036)$ lower $(23.71$ $(8.17-52.71) \mathrm{ng} / \mathrm{ml})$ than in children with reactive arthritis - $27.44(11.84-45.81) \mathrm{ng} / \mathrm{ml}$. The available literature does not report any difference in vitamin D levels between JIA and ReA patients. De Sousa Studart et al. (2015) found that vitamin D levels were higher in JIA patients than in a control group, which might be due to vitamin D substitution in the JIA patient group. In another study, patients with JIA showed statistically significant lower levels of $25(\mathrm{OH})$ vitamin D compared to a control group $(p<0.001)$, which was also observed for different forms of JIA (oligoarticular form $-p<0.05$; polyarticular form $-p<0.005$; systemic form $-p<0.001$; enthesitis associated form $-p<0.005$ ) (Stagi et al. 2014).

In our study, positive correlation between ESR and vitamin $\mathrm{D}$ was found $(\mathrm{r}=0.303 ; p=0.007)$, which was also found in the severe form JIA patient group $(\mathrm{r}=0.769 ; p=0.001)$. These correlations contradict previous studies that found negative correlations, which are currently explained by the potential properties of vitamin $\mathrm{D}$ to reduce autoimmune disease activity. For example, Kavellou-Athanassiou et al. (2012) found a negative correlation between ESR and vitamin D levels $(r=-0.18)$ in a study on effect of vitamin D effect on RA disease activity. In a study on 294 patients with type 2 diabetes mellitus (Kaya et al. 2018), ESR was higher in patients with vitamin D deficiency $(p<0.001)$ and there was a negative correlation between ESR and vitamin $\mathrm{D}$ level $(\mathrm{r}=0.256 ; p<0.001)$. However, there are studies where no association between vitamin D levels and ESR was found (Yildirin et al., 2013).

Positive correlations have also been found between vitamin $\mathrm{D}$ and TNF-alpha levels $(\mathrm{r}=0.347 ; p=0.009)$, which is contrary to current literature, where a negative correlation is described (Peterson et al., 2008; Bellia et al., 2013; de Souza et al., 2016; Elizondo-Montemayor et al., 2017). Rodriguez et al. (2018) in a meta-analysis showed that patients given vitamin D had lower levels of TNF-alpha compared to control groups $(\mathrm{n}=0.380 ; p=0.04)$. Azizieh et al. $(2016)$ found that there was no statistically significant difference between TNF- $\alpha$ levels in women with vitamin D deficiency (in this case below $25 \mathrm{nmol} / \mathrm{l}$ ) compared to those with levels higher than $25 \mathrm{nmol} / \mathrm{l}(p=0.724)$, although the mean level of TNF- $\alpha$ was slightly higher in the vitamin D deficiency group (9.90 vs. $9.75 \mathrm{pg} / \mathrm{ml}$ ). In our study, patients with vitamin D levels below $30 \mathrm{ng} / \mathrm{ml}$ had, on average, a lower TNF- $\alpha$ level $(6.82 \pm 2.68 \mathrm{pg} / \mathrm{ml})$ compared to patients with levels higher than $30 \mathrm{ng} / \mathrm{ml}(8.11 \pm 3.70 \mathrm{pg} / \mathrm{ml})$, but this difference was not significant $(p=0.688)$.
The statistically significant positive correlations found between vitamin D levels and ESR $(r=0.303 ; p=0.007)$ and TNF-alpha levels $(r=0.347 ; p=0.009)$ require further study.

Several studies have found a negative correlation between vitamin D level and CRP: for example, KavellouAthanassiou et al. (2012) - r $=0.115$, Eleftheriadis et al. (2012) - $\mathrm{r}=-0.360 ; p=0.04$, Ashraf et al. (2012) $-\mathrm{r}=$ $-0.25 ; p=0.049$, Wang et al. (2018) - $\mathrm{r}=0.231 ; p=$ 0.004 . Some studies did not find such correlation (Petersen et al., 2008; Michos et al., 2009; Yildirin et al., 2013). Also, our data showed no statistically significant correlation in any group of patients: neither in all included patients $(\mathrm{r}=$ $0.044 ; p=0.687)$ nor in the JIA group $(\mathrm{r}=0.092 ; p=$ $0.521)$, nor in patients with $\operatorname{ReA}(\mathrm{r}=-0.013 ; p=0.941)$.

JIA patients in our study were significantly more likely to have positive antinuclear antibodies (ANA) compared to ReA patients $(p=0.029)$. Comparison of vitamin D levels in ANA positive patients and ANA negative patients suggests that D vitamin is significantly lower in ANA positive patients (17.4 versus $29.4 \mathrm{ng} / \mathrm{ml} ; p<0.01)$. Also, Ritterhouse et al. (2011) reported that ANA positive SLE patients were more likely to have vitamin D deficiency (below 20 $\mathrm{ng} / \mathrm{ml}$ ) compared to ANA negative SLE patients ( $p=$ $0.011)$.

Literature provides data on negative correlation between vitamin D and anti-DNA antibody levels (Bonakdar et al., 2011; Szodoray et al., 2011; Mok et al., 2012; AlSaleeme et al., 2015). For example, Mok et al. (2012) reported a weak negative correlation $(\mathrm{r}=-0.13 ; p=0.02)$. Our study also found significant negative correlation between vitamin $\mathrm{D}$ and anti-DNA antibody levels in patients with reactive arthritis $(\mathrm{r}=0.401 ; p=0.017)$. On the other hand, Thudi et al. (2008) found a higher anti-dsDNA titre in a small systemic lupus erythematosus (SLE) patient cohort with vitamin D levels higher than $47.7 \mathrm{nmol} / \mathrm{l}$, compared to patients with 25 $(\mathrm{OH})$ D lower than $47.7 \mathrm{nmol} / \mathrm{l}(p=0.0069)(\mathrm{n}=37)$. Our study also found a significant difference between anti-DNA antibody levels in patients with and without vitamin D deficiency $(8.15 \pm 5.86$ versus $8.61 \pm 6.61 \mathrm{IU} / \mathrm{ml} ; p=0.013)$.

There was no association between vitamin D and haemoglobin level $(\mathrm{r}=-0.041 ; p=0.701)$. Also, Ernst et al., 2016) observed that vitamin $\mathrm{D}$ therapy had no effect on anaemia patients. In a study of 50 children diagnosed with sickle cell anaemia (Busse et al. 2013), a negative association occurred between vitamin $\mathrm{D}$ and haemoglobin levels $(p=0.017)$.

The effect of vitamin D on the number of leukocytes is contradictory in the literature. De Oliveira et al. (2017) describe a negative correlation between these parameters. In contrast, Soliman et al. (2012) found no relationship between vitamin D level and red blood cell count, nor between vitamin $\mathrm{D}$ and white blood cell count. In our study, total number of leukocytes (WBC) in both JIA and ReA patients was on average $8.08 \pm 2.89(4-20.2)$ thousands per $1 \mathrm{~mm}^{3}$ of peripheral blood. There were no significant differences in the 
number of leukocytes between JIA and ReA patients ( $p=$ $0.153)$

Similar to Zostautiene et al. (2016), we also did not find a statistically significant correlation between vitamin D levels and the birth season $(\mathrm{r}=0.395, p=0.204)$. However, it should be noted that the patients included in the study were generally born during the "dark "months of the year (57:43), which suggest that children born in these months have a tendency to rheumatic diseases. This phenomenon could not be explained by a general increase in birth rates during the "dark" months of the year, as more children are born in the summer months, according to information published on the Central Statistical Bureau of Latvia website. It is possible that a child's birth season affects the risk of developing rheumatologic diseases, because the mothers of these children have had a vitamin D deficiency during their pregnancy. For example, Molla et al. (2005) show that $40 \%$ of mothers and $60 \%$ of newborns have vitamin D deficiency on their birthday and these values were closely correlated $(\mathrm{r}=0.790, p<0.001)$. Also, Nesby-O'Dell et al. (2002) pointed out that one of the main risk factors for infant vitamin $\mathrm{D}$ deficiency is deficiency in mothers during pregnancy.

Since individual authors have discovered that neither the oral administration of vitamin $\mathrm{D}$ to patients nor exposure to sunlight has a significant effect on 25-(OH) D levels (Elizondo-Montemayor et al., 2017), apparently there are still unknown factors determining level of vitamin D.

\section{CONCLUSIONS}

Vitamin D deficiency is common among both JIA and reactive arthritis patients. Overall, average the vitamin D level among all patients included in the study was $25.26 \pm 9.02$ $\mathrm{ng} / \mathrm{ml}$. In children with JIA, vitamin D levels were significantly lower compared to children with reactive arthritis $(p=0.036)$.

The vitamin D levels in girls were lower than in boys ( $p=$ $0.022)$. There was a significant moderate negative correlation between vitamin $\mathrm{D}$ level and patient age $(\mathrm{r}=0.443 ; p=$ $0)$. There was a weak negative correlation between vitamin D level and BMI, which was statistically significant $(\mathrm{r}=$ $0.372, p=0.002$ ).

Detected positive correlations between vitamin $\mathrm{D}$ levels and ESR $(r=0.303 ; p=0.007)$ and TNF-alpha levels $(r=0.347$; $p=0.009)$ require further study.

\section{REFERENCES}

Abudawood, M., Tabassum, H., Ansar, S., Almosa, K., Sobki, S., Ali, M. N., Aljohi, A. (2018). Assessment of gender-related differences in vitamin D levels and cardiovascular risk factors in Saudi patients with type 2 diabetes mellitus. Saudi J. Biol. Sci., 25 (1), 31-36.

Ahmadieh, H., Azar, S. T., Lakkis, N., Arabi, A. (2013). Hypovitaminosis d in patients with type 2 diabetes mellitus: A relation to disease control and complications. ISRN Endocronol., 2013, doi: 10.1155/2013/641098.
AlSaleem, A., AlSaghier, A., Al-Mayouf, S. M. (2015). Vitamin D status in children with systemic lupus erythematosus and its association with clinical and laboratory parameters. Clin. Rheumatol., 34 (1), 81-84.

Anonymous (2014). Vitamin D levels suboptimal for 1 in 10 US children. Reuters Health Information. 10 April 2014.

Ashraf, A. P., Fisher, G., Alvarez, J., Dudenbostel, T., Calhoun, D. A., Szalai, A. J., Gower, B. A. (2012). Associations of C-reactive protein to indices of vascular health and the influence of serum $25(\mathrm{OH}) \mathrm{D}$ status in healthy adults. J. Nutr. Metab., 2012, doi: 10.1155/2012/475975.

Atwa, M. A., Balata, M. G., Hussein, A. M., Abdelrahman, N. I., Elminshawy, H. H. (2013). Serum 25-hydroxyvitamin D concentration in patients with psoriasis and rheumatoid arthritis and its association with disease activity and serum tumor necrosis factor-alpha. Saudi Med., J., 34 (8), 806-813.

Azizieh, F., Alyahya, K. O., Raghupathy, R. (2016). Association between levels of vitamin D and inflammatory markers in healthy women. $J$. Inflamm. Res., 9, 51-57.

Bani-issa, W., Eldeirawi, K., Harfil, S., Fakhry, R. (2017). Vitamin D deficiency and its determinants in adults: A sample from community-based settings in the United Arab Emirates. Int. J. Endocrinol., 2017, Article ID 3906306 .

Bellia, A., Garcovich, C., D’Adamo, M., Lombardo, M., Tesauro, M., Donadel, G., Sbraccia, P. (2013). Serum 25-hydroxyvitamin D levels are inversely associated with systemic inflammation in severe obese subjects. Intern. Emerg. Med., 8 (1), 33-40.

Bonakdar, Z. S., Jahanshahifar, L., Jahanshahifar, F., Gholamrezaei, A. (2011). Vitamin D deficiency and its association with disease activity in new cases of systemic lupus erythematosus. Lupus, 20 (11), 1155-1160.

Booth, D. R., Ding, N., Parnell, G. P., Shahijanian, F., Coulter, S., Schibeci, S. D., Atkins, A.R., Stewart, G.J., Evans, R.M., Downes, M., Liddle, C. (2016). Cistromic and genetic evidence that the vitamin D receptor mediates susceptibility to latitude-dependent autoimmune diseases. Genes Immun., 17 (4), 213-219.

Busse, J. A., Seelaboyina, K. N., Malonga, G., Setty, M. J., Moulton, T. (2013). Vitamin D level and its correlation with hemoglobin in pediatric sickle cell disease patients. Blood, 122, 4677.

Cantorna, M. T. (2000). Vitamin D and autoimmunity: Is vitamin D status an environmental factor affecting autoimmune disease prevalence? (44485). Proc. Soc. Exper. Biol. Med., 223 (3), 230-233.

Cantorna, M. T., Zhu, Y., Froicu, M., Wittke, A. (2004). Vitamin D status, 1, 25-dihydroxyvitamin D3, and the immune system. Amer. J. Clin. Nutr., 80 (6), 1717S-1720S.

Cashman, K. D., Dowling, K. G., Škrabáková, Z., Gonzalez-Gross, M., Valtueńa, J., De Henauw, S., Moreno, L., Damsgaard, C. T., Michaelsen, K. F., Mølgaard, C., Jorde, R., Grimnes, G., Moschonis, G., Mavrogianni, C., Manios, Y., Thamm, M., Mensink, G. B., Rabenberg, M., Busch, M. A., Cox, L., Meadows, S., Goldberg, G., Prentice, A., Dekker, J. M., Nijpels, G., Pilz, S., Swart, K. M., van Schoor, N. M., Lips, P., Eiriksdottir, G., Gudnason, V., Cotch, M. F., Koskinen, S., Lamberg-Allardt, C., Durazo-Arvizu, R. A., Sempos, C. T., Kiely, M. (2016). Vitamin D deficiency in Europe: pandemic. Amer. J. Clin. Nutr., 103 (4), 1033-1044.

Cheng, S., Massaro, J. M., Fox, C. S., Larson, M. G., Keyes, M. J., McCabe, E. L., Booth, S. L. (2010). Adiposity, cardiometabolic risk, and vitamin D status: The Framingham Heart Study. Diabetes, 59 (1), 242-248.

Christakos, S., Dhawan, P., Liu, Y., Peng, X., Porta, A. (2003). New insights into the mechanisms of vitamin D action. J. Cell.Biochem., 88 (4), 695-705.

Cieślińska, A., Kostyra, E., Chwała, B., Moszyñska-Dumara, M., Fiedorowicz. E., Teodorowicz, M., Savelkoul, H. F. J. (2017).Vitamin D receptor gene polymorphisms associated with childhood autism. Brain Sci., 7 (9), 115.

Çomak, E., Doğan, Ç. S., Uslu-Gökçeoğlu, A., Akbaş, H., Özdem, S., Koyun, M., Akman, S. (2014). Association between vitamin D deficiency 
and disease activity in juvenile idiopathic arthritis. Turkish J. Pediatr., 56 (6), 626-631.

De Oliveira, C., Biddulph, J. P., Hirani, V., Schneider, I. J. C. (2017). Vitamin D and inflammatory markers: Cross-sectional analyses using data from the English Longitudinal Study of Ageing (ELSA). J. Nutr. Sci., 6, doi: $10.1017 /$ jns.2016.37

de Sousa Studart, S. A., Leite, A. C. R. M., Marinho, A. L. L. F., Pinto, A. C. M. D., Jśnior, C. N. R., de Melo Nunes, R., Rocha, F. A. C. (2015). Vitamin $\mathrm{D}$ levels in juvenile idiopathic arthritis from an equatorial region. Rheumatol. Int., 35 (10), 1717-1723.

de Souza, W. N., Norde, M. M., Oki, É., Rogero, M. M., Marchioni, D. M., Fisberg, R. M., Martini, L. A. (2016). Association between 25-hydroxyvitamin $\mathrm{D}$ and inflammatory biomarker levels in a cross-sectional population-based study, Sćo Paulo, Brazil. Nutr. Res., 36 (1), 1-8.

Drincic, A. T., Armas, L. A., Van Diest, E. E., Heaney, R. P. (2012). Volumetric dilution rather than sequestration best explains the low vitamin D status of obesity. Obesity, 20 (7), 1444-1448.

Eleftheriadis, T., Antoniadi, G., Liakopoulos, V., Stefanidis, I., Galaktidou, G. (2012). Inverse association of serum 25-hydroxyvitamin D with markers of inflammation and suppression of osteoclastic activity in hemodialysis patients. Iran. J. Kidney Kidney Dis., 6 (2), 129-135.

Elizondo-Montemayor, L., Castillo, E. C., Rodríguez-López, C., Villarreal-Calderón, J. R., Gómez-Carmona, M., Tenorio-Martínez, S., Nieblas, B., García-Rivas, G. (2017). Seasonal variation in vitamin D in association with age, inflammatory cytokines, anthropometric parameters, and lifestyle factors in older adults. Mediators Inflamm., 2017, doi: $10.1155 / 2017 / 5719461$

Ernst, J. B., Tomaschitz, A., Grübler, M. R., Gaksch, M., Kienreich, K., Verheyen, N., Zittermann, A. (2016). Vitamin D supplementation and hemoglobin levels in hypertensive patients: A randomized controlled trial. Int. J. Endocrinol., 2016, article ID 6836402.

Gharaibeh, M. A., Stoecker, B. J. (2009). Assessment of serum 25 (OH) D concentration in women of childbearing age and their preschool children in Northern Jordan during summer. Eur. J. Clin. Nutr., 63 (11), 1320-1326.

Hajjaj-Hassouni, N., Mawani, N., Allali, F., Rkain, H., Hassouni, K., Hmamouchi, I., Dougados, M. (2017). Evaluation of vitamin D status in rheumatoid arthritis and its association with disease activity across 15 countries: "The COMORA Study". Int. J. Rheumatol., 2017, doi: $10.1155 / 2017 / 5491676$

Ikeda, U., Wakita, D., Ohkuri, T., Chamoto, K., Kitamura, H., Iwakura, Y., Nishimura, T. (2010). 1i, 25-Dihydroxyvitamin D3 and all-trans retinoic acid synergistically inhibit the differentiation and expansion of Th17 cells. Immunol. Lett., 134 (1), 7-16.

Inanir, A., Özoran, K., Tutkak, H., Mermerci, B. (2004). The effects of calcitriol therapy on serum interleukin-1, interleukin-6 and tumour necrosis factor- $i$ concentrations in post-menopausal patients with osteoporosis. J. Int. Med. Res., 32 (6), 570-582.

Jeng, L., Yamshchikov, A. V., Judd, S. E., Blumberg, H. M., Martin, G. S., Ziegler, T. R., Tangpricha, V. (2009). Alterations in vitamin D status and anti-microbial peptide levels in patients in the intensive care unit with sepsis. J. Transl. Med., 7 (1), 28.

Kumaratne, M., Early, G., Cisneros, J. (2017). Vitamin D deficiency and association with body mass index and lipid levels in Hispanic American adolescents. Global Pediatric Health, 4, 2333794X17744141.

Lippi, G., Bonelli, P., Buonocore, R., Aloe, R. (2015). Birth season and vitamin D concentration in adulthood. Ann. Transl. Med., 3 (16), 231

Mangin, M., Sinha, R., Fincher, K. (2014). Inflammation and vitamin D: The infection connection. Inflamm. Res., 63 (10), 803-819.

Michos, E. D., Streeten, E. A., Ryan, K. A., Rampersaud, E., Peyser, P. A., Bielak, L. F., Post, W. (2009). Serum 25-hydroxyvitamin d levels are not associated with subclinical vascular disease or C-reactive protein in the old order amish. Calcif. Tiss. Int.,, 84 (3), 195-202.
Mithal, A., Wahl, D. A., Bonjour, J. P., Burckhardt, P., Dawson-Hughes, B., Eisman, J. A., El-Hajj Fuleihan, G., Josse, R. G., Lips, P., Morales-Torres, J.; IOF Committee of Scientific Advisors (CSA) Nutrition Working Group (2009). Global vitamin D status and determinants of hypovitaminosis D. Osteoporosis Int., 20 (11), 1807-1820.

Mok, C. C., Birmingham, D. J., Ho, L. Y., Hebert, L. A., Song, H., Rovin, B H. (2012). Vitamin D deficiency as marker for disease activity and damage in systemic lupus erythematosus: A comparison with anti-dsDNA and anti-C1q. Lupus, 21 (1), 36-42.

Molla, A. M., Al Badawi, M., Hammoud, M. S., Molla, A. M., Shukkur, M., Thalib, L., Eliwa, M. S. (2005). Vitamin D status of mothers and their neonates in Kuwait. Pediatr. Int., 47 (6), 649-652.

Mukane, M., Rasa, I., Mukans, M. (2016). First epidemiological study about vitamin D status and lifestyle factors in healthy young adults from Latvia: DLAT study, 2012. Osteoporos. Int., 27 (1).

Myszka, M., Klinger, M. (2014). The immunomodulatory role of Vitamin D. Postepy higieny i medycyny doswiadczalnej, 68, 865-878.

Nesby-O'Dell, S., Scanlon, K. S., Cogswell, M. E., Gillespie, C., Hollis, B. W., Looker, A. C., Allen, C., Doughertly, C., Gunter, E.W., Bowman, B. A. (2002). Hypovitaminosis D prevalence and determinants among African American and white women of reproductive age: Third National Health and Nutrition Examination Survey, 1988-1994. Amer J. Clin. Nutr., 76 (1), $187-192$.

Penna, G., Adorini, L. (2000). 1 $\alpha, 25$-dihydroxyvitamin D3 inhibits differentiation, maturation, activation, and survival of dendritic cells leading to impaired alloreactive T cell activation. J. Immunol., 164 (5), 2405-2411.

Peterson, C. A., Heffernan, M. E. (2008). Serum tumor necrosis factor-alpha concentrations are negatively correlated with serum $25(\mathrm{OH})$ D concentrations in healthy women. J. Inflamm., 5 (1), 10.

Pike, J. W., Meyer, M. B. (2012). The vitamin D receptor: New paradigms for the regulation of gene expression by 1, 25-dihydroxyvitamin D3. Rheum. Dis. Clin., 38 (1), 13-27.

Popa, C., Netea, M. G., Van Riel, P. L., Van Der Meer, J. W., Stalenhoef, A. F. (2007). The role of TNF- $\alpha$ in chronic inflammatory conditions, intermediary metabolism, and cardiovascular risk. J. Lipid. Res., 48 (4), 751-762.

Pu, D., Luo, J., Wang, Y., Ju, B., Lv, X., Fan, P., He, L. (2018). Prevalence of depression and anxiety in rheumatoid arthritis patients and their associations with serum vitamin D level. Clin. Rheumatol., 37 (1), 179-184.

Raman, M., Milestone, A. N., Walters, J. R., Hart, A. L., Ghosh, S. (2011). Vitamin D and gastrointestinal diseases: Inflammatory bowel disease and colorectal cancer. Ther. Adv. Gastroenterol., 4 (1), 49-62.

Ritterhouse, L. L., Crowe, S. R., Niewold, T. B., Kamen, D. L., Macwana, S. R., Roberts, V. C., James, J. A. (2011). Vitamin D deficiency is associated with an increased autoimmune response in healthy individuals and in patients with systemic lupus erythematosus. Ann. Rheum. Dis., 70 (9), 1569-1574.

Rodriguez, A. J., Mousa, A., Ebeling, P. R., Scott, D., de Courten, B. (2018) Effects of vitamin D supplementation on inflammatory markers in heart failure: A systematic review and meta-analysis of randomized controlled trials. Sci. Rep., 8 (1), 1169.

Rovner, A. J., O’Brien, K. O. (2008). Hypovitaminosis D among healthy children in the United States: A review of the current evidence. Arch. Ped. Adolesc. Med., 162 (6), 513-519.

Sadiya, A., Ahmed, S. M., Skaria, S., Abusnana, S. (2014). Vitamin D status and its relationship with metabolic markers in persons with obesity and type 2 diabetes in the UAE: A cross-sectional study. J. Diabetes Res., 2014 doi: $10.1155 / 2014 / 869307$

Schleithoff, S. S., Zittermann, A., Tenderich, G., Berthold, H. K., Stehle, P., Koerfer, R. (2006). Vitamin D supplementation improves cytokine profiles in patients with congestive heart failure: A double-blind, randomized, placebo-controlled trial. Amer. J. Clin. Nutr., 83 (4), 754-759.

Semjonova, J., Rasa, I. (2012). 25 (OH)D3 Status Among Adults in Latvia In: 4th International Interdisciplinary Scientific Conference, Rīga, Novem- 
ber 22-23, 2012. Society, Health, Welfare. Abstracts. Rīga: Rīgas Stradina Universitāte, pp. 95-95.

Soliman, A. T., Eldabbagh, M., Elawwa, A., Saleem, W. (2012). Does vitamin D therapy affect hematological indices in adolescents with vitamin D deficiency? Indian J. Endocrinol. Metab., 16 (4), 659-660.

Staeva-Vieira, T. P., Freedman, L. P. (2002). 1, 25-dihydroxyvitamin D3 inhibits IFN- $\gamma$ and IL-4 levels during in vitro polarization of primary murine CD4+ T cells. J. Immunol., 168 (3), 1181-1189.

Stagi, S., Cavalli, L., Bertini, F., Martino, M. D., Cerinic, M. M., Brandi, M. L., Falcini, F. (2014). Vitamin D levels in children, adolescents, and young adults with juvenile-onset systemic lupus erythematosus: A cross-sectional study. Lupus, 23 (10), 1059-1065.

Szodoray, P., Tarr, T., Bazso, A., Poor, G., Szegedi, G., Kiss, E. (2011). The immunopathological role of vitamin D in patients with SLE: Data from a single centre registry in Hungary. Scand. J. Rheumatol., 40 (2), 122-126.

Thudi, A., Yin, S. U., Wandstrat, A. E., Olsen, N. J., Li, Q. Z. (2008). Vitamin D levels and disease status in Texas patients with systemic lupus erythematosus. Amer. J. Med. Sci., 335 (2), 99-104.

Tizaoui, K., Hamzaoui, K. (2015). Association between VDR polymorphisms and rheumatoid arthritis disease: Systematic review and up- dated meta-analysis of case-control studies. Immunobiology, 220 (6), 807-816.

Verdoia, M., Schaffer, A., Barbieri, L., Di Giovine, G., Marino, P., Suryapranata, H., De Luca, G.; Novara Atherosclerosis Study Group. (2015). Impact of gender difference on vitamin D status and its relationship with the extent of coronary artery disease. Nutr. Metab. Cardiovasc. Dis., 25 (5), 464-470.

Wortsman, J., Matsuoka, L. Y., Chen, T. C., Lu, Z., Holick, M. F. (2000). Decreased bioavailability of vitamin D in obesity. Amer. J. Clin. Nutr., 72 (3), 690-693.

Yasmin, R., Williams, R. M., Xu, M., Noy, N. (2005). Nuclear import of the retinoid $\mathrm{X}$ receptor, the vitamin $\mathrm{D}$ receptor, and their mutual heterodimer. J. Biol. Chem., 280 (48), 40152-40160.

Yildirim, I., Hur, E., Kokturk, F. (2013). Inflammatory markers: C-reactive protein, erythrocyte sedimentation rate, and leukocyte count in vitamin D deficient patients with and without chronic kidney disease. Int. J. Endocrinol., 2013, doi: 10.1155/2013/802165.

Zostautiene, I., Jorde, R., Grimnes, G. (2016). No association between birth season and vitamin D concentration in adults in a North Norwegian population: The Tromso study. Ann. Transl. Med., 4 (1): 20, doi: $0.3978 / \mathrm{j}$. issn.2305-5839.2015.12.54.

Received 19 May 2019

Accepted in the final form 17 June 2019

\section{5 - HIDROKSIVITAMĪNA D LĪMENIS PACIENTIEM AR JUVENĪLU IDIOPĀTISKU ARTRĪTU UN REAKTĪVU ARTRĪTU}

D vitamīna deficìts ir plaši izplatīts un sastopams visā pasaulē. Lai gan jau vairākus gadus ir zināms, ka D vitamīnam piemīt imūnmodulators efekts, joprojām nav skaidrs, vai tā deficīts ir asociēts ar augstāku slimības aktivitāti reimatoloğiskajiem pacientiem. Šì retrospektīvā pētījuma mērkis bija noskaidrot D vitamīna līmeni bērniem ar juvenīlu artrītu un reaktīvu artrītu. Pētījumā tika noskaidrota D hipovitaminozes prevalence 98 bērniem ar juvenīlo idiopātisko artrītu (JIA) un reaktīvo artrītu (ReA), kā arī meklētas asociācijas starp seruma D vitamīna koncentrāciju un slimību aktivitātes markieriem. Pētījumā iesaistìtajiem pacientiem D vitamīna deficīts bija novērojams 69,07\% gadījumu. Bērniem ar JIA D vitamīna līmenis bija statistiski ticami zemāks, salīdzinot ar bērniem, kuriem bija reaktîvs artrīts. Tika konstatēta arī statistiski ticama vidēji cieša negatīva korelācija starp D vitamīna līmeni un pacienta vecumu, kā arī vāja negatīva korelācija starp D vitamīna līmeni un kermeṇa masas indeksu. Noskaidrotās atsevišḳās korelācijas ar iekaisuma markieriem parāda, ka nepieciešama turpmāka D vitamīna un slimības aktivitātes asociāciju izpēte. 